\title{
The Hollow State: Rural Governance in China
}

\author{
Graeme Smith $^{*}$
}

\begin{abstract}
Over the last decade, rural township governments have been subjected to intensive streamlining and rationalization programmes. This article examines which ongoing reforms and processes are causing township governments to become "hollow shells," and explores the effects of "hollowing out" on township government leaders, staff and rural residents. While the aim of local government reform was to transform extractive township governments into "service-oriented" agencies, this article finds that the current logic of rural governance has produced township governments which are squeezed from above and below. From above, township leaders face the political imperatives of inspections, annual assessments, the need to attract industrial investment and an ongoing process of "soft centralization" by higher levels of government. From below, township staff are drawn out to the villages to enforce family planning policies and maintain social stability. Unprecedented numbers are working as "sent-down cadres" in villages where their capacity to deliver services has been weakened by village amalgamations and the lifting of agricultural taxes and fees. Despite significant boosts to rural health and education investment, rural residents still face a level of government that regards them as problems to be dealt with, rather than citizens to be served.
\end{abstract}

Increasing attention has been paid to the phenomenon of rural township governments being "hollowed out" in the wake of rural taxation reforms, ${ }^{1}$ but there is a lack of detailed ethnographic information on the effects of this phenomenon. This article is a detailed study of the lowest formal level of the Chinese state at the township level. Its starting point is the perspective of township government officials and ordinary staff themselves. I explore how township governments have become hollow administrative shells and the specific processes which are the basis for this "hollowing out," and examine the implications for local

* Australian National University. Email: graeme.smith@anu.edu.au

1 See esp. John James Kennedy, "From the tax-for-fee reform to the abolition of agricultural taxes: the impact on township governments in north-west China," The China Quarterly, No. 189 (2007), pp. 4359; and Linda Chelan Li, "Working for the peasants? Strategic interactions and unintended consequences in China's rural tax reform," The China Journal, No. 57 (2007), pp. 90-106. 
government in rural China. Nearly all studies in the Western literature have tended to focus on either county or village governments with few examining the inner workings of township governments, thus leaving the lowest level of formal administration as something of a lacuna in China studies. In this article, taking a county in central China's rural heartland as my case study, I examine how the local state functions at the township level, using surveys and extensive interviews with county officials, township government workers, village cadres and ordinary rural residents.

Previous authors have accurately described township governments as hollow "administrative shells," unable to provide basic services in the wake of tax-for-fee reform during the 1990s and the abolition of agricultural taxes in 2006. However, the mechanisms of hollowing out have not been fully elucidated. This article argues that it is not just a consequence of the tax-for-fee reforms, but rather is constantly reinforced by the revenue-raising and political imperatives faced by township leaders, exacerbated by recent administrative reforms.

The first section details pressures from the county level in the form of higherlevel inspections, the pressure to attract investment and the "soft centralization"2 of township agencies. These pressures are hollowing township governments from above by drawing township leaders and the most talented staff away from their bailiwicks, thus transforming township governments into service agencies for county leaders. The second section describes hollowing from below. In the past, township governments guided village work, but with village governments starved of revenue following the abolition of agricultural taxes in 2006 and the ranks of village cadres depleted by village amalgamations, township government workers are now undertaking tasks that were formerly shouldered by villages. Unprecedented numbers of township staff are working as "sent-down" village cadres to enforce the key political imperatives of family planning and social stability. I draw conclusions on how this hollowing process changes the nature of the local state, and how this affects attempts to transform township governments into service-oriented agencies.

This article is a result of extensive fieldwork conducted in 16 townships in a relatively well-off county in Anhui province, referred to as Benghai. ${ }^{3}$ Anhui was chosen because it was the pioneer in both tax-for-fee reforms during the 1990s. The county boasts a range of agricultural products in keeping with its varied geography. Its GDP per capita in 2010 was slightly higher than the provincial average because of the presence of many successful rural industries. When agricultural taxes were abolished in 2006 the impact on government revenue was negligible, as agricultural taxes had accounted for less than 10 per cent of the county's taxes.

2 Andrew Mertha, "China's 'soft' centralization: shifting tiao/kuai authority relations," The China Quarterly, No. 184 (2005), pp. 791-810.

3 Due to the need to protect sources, Benghai is a pseudonym. 
From 2004 to 2008, I spent 21 months in Benghai county, working within the county government on poverty alleviation projects related to agriculture, education and forestry. As a result, I worked closely with township and county government officials on a daily basis, allowing me to obtain information beyond the scope of formal interviews. Surveys of 286 farm households in five different townships were conducted with research teams in 2004, 2005 and 2008 to obtain background information on rural residents' experiences of taxation, land use, village amalgamations and interaction with local cadres.

A survey of 95 township government staff in all 16 townships was conducted with the assistance of the Ministry of Agriculture between January and March 2006. Extensive follow-up interviews with township staff and ordinary farmers also took place. Interviews were conducted either at my residence in the county seat or at the residences of interviewees. These provided a more nuanced picture of their behaviour, allowed them to frame and discuss issues in their own terms and to construct their own narratives of experiences with the local government. Interviews were also conducted with academics, officials and businesspeople in the prefectural capital, as well as Hefei, Beijing and Sichuan.

In addition to this ethnography, I draw upon the work of three Chinese researchers who examine the day-to-day workings of township governments. Zhao Shukai 赵树凯, from the State Council's Development Research Centre, surveyed 20 township governments in ten different provinces, spending a considerable time in each township and inviting all the township Party secretaries to Beijing for in-depth discussions. ${ }^{4} \mathrm{Gu}$ Wenfeng 谷文峰, a sociologist, was posted by the Henan provincial government to a township in Hebi prefecture, and detailed his experiences during two years as a township Party secretary. ${ }^{5}$ The renowned political sociologist from the "Central China School" of rural studies, Wu Yi 吴毅, spent a year with the cadres of a township in central China. ${ }^{6}$

\section{Hollowed from Above}

In this section, I argue that township governments in central China have been hollowed out from above by three imperatives: the need to attract investment to compensate for lost revenue and meet the political imperatives set by county and provincial governments; the need to receive inspection teams from higher levels of government; and "soft centralization" of township bureaus, which are placed under county or provincial government control.

4 Zhao Shukai, "Rural governance in the midst of underfunding, deception, and mistrust," in Andrew Kipnis and Graeme Smith (eds.), Chinese Sociology \& Anthropology, No. 39 (2007).

$5 \mathrm{Gu}$ Wenfeng, Feichang zishu: yi ge xiangzhen shuji de meng yu teng (Extraordinary Accounts: the Hopes and Troubles of a Township Party Secretary) (Beijing: Xinhua chubanshe, 2006).

$6 \mathrm{Wu}$ Yi, Xiao zhen xuanxiao: yi ge xiangzhen zhengzhi yunzuo de yanyi yu chanshi (Uproar in a Small Town: Interpretation of a Township's Political Operation) (Beijing: Sanlian shudian, 2007). 


\section{Attracting investment}

What functions does the township government serve, and how do ordinary township government staff perceive the priorities of the local state? To address these questions, I asked township staff what, to them, were the main tasks of the township government, compared to 1999, the height of the Jiang era, and the 1980s. The figure represents the percentage of staff who saw the task as a major (in the top five of ten tasks) priority of the township government during the specified time period. Items which score more than 50 per cent in this category are major priorities and are highlighted in bold in Table 1 .

Table 1 suggests that national Party policies (panel b) now have more influence on Benghai's township governments than during the Jiang Zemin era, when the pressure from higher levels of government to collect taxes (panel $j$ ) was paramount. ${ }^{7}$ However, the third-ranked item in 2006, attracting investment (panel $\mathrm{g}$ ), is a priority of provincial and sub-provincial Party leaders, and has repeatedly been criticized by national Party leaders.

Even the most impoverished townships are devoting resources and staff towards attracting investment. In one remote township, 16 of the 55 formally employed staff were members of the investment working group, including staff from 13 different bureaus, as well as the township Party secretary, the township head and a deputy Party secretary. ${ }^{8}$ Wealthier townships produce glossy investment guide books which describe projects that are seeking investment, and detail the tax and land incentives available to prospective investors. Typically, a tax-free period of three years is offered, as well as low land rental rates (as little as one yuan per square metre, or even free for a certain period). Most townships had set up agencies specifically to solicit investment, but ultimate responsibility lay with the township head and the Party secretary.

Chinese scholars have questioned the value of each province, prefecture, county, township and even village competing to offer the most attractive package to investors. ${ }^{9}$ Setting quotas for attracting investment encourages township officials to falsify reports and force local businesses to register as "outside" or, better yet, "foreign" investors. ${ }^{10}$ Funds that could be used to provide services for rural residents are instead spent on entertaining prospective investors. This situation is

7 For an account of how township governments adapted to higher-level pressure to collect taxes during the reform period, see Tian Yi and Zhao Xu, Ta xiang zhi shui (Township Taxes) (Beijing: Zhongxin chubanshe, 2008).

8 It is near impossible to know how many staff are on the payroll of a township government. Gu estimated that 69 cadres were on his official payroll, but 124 drew a salary (or 150 if laid-off and retired staff were included): Gu Wenfeng, Extraordinary Accounts, p. 145.

9 See esp. Zhao Shukai, "Rural governance," pp. 68-73; Wu Licai and Zhu Hongxuan, "Xiangzhen gaige: xiangzhen ganbu de suo si suo xiang - dui Hubei sheng xiangzhen ganbu de wenjuan diaocha" ("Township reform: what township cadres think - a survey of Hubei province"), Zhongguo nongcun jingji (China Rural Economy), No. 11 (2005), p. 64.

10 Contrast this with Kellee Tsai's description of Chinese businesses registering as foreign-invested enterprises to enhance their status and thus reduce interference from local government. Kellee S. Tsai, Capitalism without Democracy (Ithica: Cornell University Press, 2007), pp. 183-88. In Benghai, local cadres pressure businesses to register outside the county to enhance their personal political prospects. 
Table 1: Priorities of Township Governments (\%)

\section{Task}

$\begin{array}{ccc}\mathbf{2 0 0 6} & \mathbf{1 9 9 9} & \mathbf{1 9 8 0 s} \\ \mathbf{5 1} & \mathbf{7 5} & \mathbf{7 5} \\ \mathbf{7 6} & \mathbf{5 8} & \mathbf{6 3} \\ 46 & 9 & 3 \\ \mathbf{5 4} & 23 & 24 \\ 32 & 19 & 33 \\ \mathbf{5 0} & 35 & 32 \\ \mathbf{7 4} & 19 & 5 \\ 38 & 39 & \mathbf{5 3} \\ \mathbf{8 6} & \mathbf{9 9} & \mathbf{7 1} \\ 0 & \mathbf{9 5} & \mathbf{9 2}\end{array}$

a) Tasks assigned by higher levels of government

b) National Party guiding principles and policies

c) Farmers' economic and political rights

d) Agricultural technology extension, information and public services

e) Developing culture, education and health

f) Public works and infrastructure, e.g. rural roads and irrigation

g) Attracting investment

h) Ensuring public stability

i) Family planning

j) Collecting tax

Source:

Author's survey, 2006, $N=95$.

unlikely to change, unless the revenue incentives and assessment criteria faced by provincial and sub-provincial authorities are altered. ${ }^{11}$ Many ordinary township staff wondered about the practicability of the policy. In the words of a township cadre who ran his own agricultural supplies business on the side:

What sorts of companies can we attract to a township like ours? We're an hour's drive from the county seat. Get serious. Profitable businesses will look for somewhere close to the big markets, with good transport and communications, somewhere like Hangzhou or Shanghai. So we land the industries no one else wants, big polluters, unprofitable industries.

This activity is driven by a series of political and economic incentives that are common to all provinces in central China. A township Party secretary from Suxian county in Henan admitted to spending two-thirds of the year "chasing the cash" in eight different provinces. ${ }^{12}$ Through meetings and the content of the townships' annual assessments, county leaders make it clear to township leaders that attracting investment is the surest way for them to earn promotion to a good county bureau and reap personal financial rewards. Attracting industrial investment also offers future revenue sources, which is why township governments tend to waive conveyancing fees. ${ }^{13}$ Because of the possibility for enrichment and travel, powerful agencies, such as the police, rural credit co-operatives and the finance bureau, tend to be over-represented in working groups for attracting investment. But quick-witted and well-connected staff are also poached from township agencies, meaning that staff left behind in the township tend to be the least talented.

11 This is common elsewhere in Anhui. My attempt to survey township staff in Wuhu county came to an abrupt end when it emerged that less than $10 \%$ of staff could be located. Their colleagues had all left the county to seek investors.

12 Liang Peng, Jiceng ganbu zhaoshang yinzi: nongmin xin liang (Making the Farmers' Blood Run Cold: Local Cadres Attracting Investment), China Elections and Governance website, 13 December 2005, http://www.chinaelections.org/NewsInfo.asp?NewsID=43318, accessed 2 July 2009.

13 Such is not the case with commercial and residential property developments. See Tao Ran, Su Fubing, Liu Mingxing and Cao Guangzhong, "Leasing and local public finance in China's regional development: evidence from prefecture-level cities," Urban Studies, forthcoming. 
The emphasis on attracting investment has increased this tendency for squandering limited township funds on food and drink. ${ }^{14}$ County documents contain detailed instructions on what sort of food should be served at banquets, strict expenditure limits (no more than 90 yuan per table for village cadres, less than 120 yuan for county leaders) and a ban on drinking at lunchtime. ${ }^{15}$ These restrictions, however, are all waived if attracting investment is the purpose of the meal. I was widely viewed as a potential "investor" and hence was a soughtafter lunch guest.

\section{Inspections}

Gu Wenfeng describes the everyday frustrations arising from the township government's lack of agency in its dealings with county and prefectural leaders:

The county has cadres who are industrious; others less so. Some cadres have no idea how to fill up their day. They'll read the smallest advertisements in the paper several times over. A newspaper and a cup of tea, that's a day's labour. But when they get fed up, it's time for an inspection of "grassroots work." They'll happily go for a tour, or perhaps score some points [on the annual assessment] by calling a meeting. They loaf around, eating and drinking for a few days, picking up "souvenirs." When the higher-level organs carry out their work, do they ever consider whether it has the slightest economic or social benefit?

As far as township cadres are concerned, I tell them to focus on results, don't worry about process. If there are petitions [by farmers to higher levels], no matter the reason, blame lies with the township. If the higher levels make work arrangements, it doesn't matter if they are relevant; tasks have to be completed otherwise criticism is swift. Regardless of funding, when you're required to accomplish something it must be done. As far as higher levels are concerned, convene a meeting, write a memorandum, issue a document and then carry out inspections. That's it. But down in the township, no matter what the circumstances, no matter what difficulties you face, the task has to be completed - no one is going to do it for you, or take responsibility. ${ }^{16}$

As Gu notes, the large number of staff at the county level increases the frequency of inspections, forcing township leaders to take staff away from their real jobs, a situation frequently described by interviewees as "not attending to one's proper duties" (bu wu zheng ye 不务正业). From a macro-perspective, the township government is effectively hollowed from within as staff and township leaders are forced to leave their posts to attend to the priority of the day. Inspections by higher levels served to remind township staff that their main duty is carrying out "key work." The head of one township agency observed:

The township leadership's work is basically about coping with all the inspections by the higherups, there's no thought of taking the lead in developing the region. Grassroots cadres need to be liberated from endless inspections and placed under the direct management of the county level. Then we won't all be dragged into work stemming from the "one-strike rejection." 17

14 See also Gu Wenfeng, Extraordinary Accounts, pp. 146-49; Wu Yi, Uproar in a Small Town, pp. 577-81.

$15 \mathrm{X}$ Town Cadre Management System (Jiguan ganbu guanli zhidu), 2008.

$16 \mathrm{Gu}$ Wenfeng, Extraordinary Accounts, pp. 101-02.

17 The "one-strike rejection" ( yi piao foujue) is applied to government tasks that have the highest priority, most consistently family planning and preventing social unrest. Failure to complete such tasks means that (at least in theory) all other achievements by the township government are annulled. See also Maria Edin, "State capacity and local agent control in China: CCP cadre management from a township 
At the beginning of each year, all staff are divided up into work groups, often attending to tasks unrelated to their actual skills. One township had over 30 such groups in 2008, with the Party secretary acting as the chair on 14 of them.

To satisfy the requirements of higher-level inspection teams, phantom agencies are created by township leaders. These "hanging sign work units" (gua paizi danwei 挂牌子单位) have no personnel assigned to them on a full-time basis. When there is an inspection, the agencies for the "new socialist countryside," industry and trade, and ecology all bustle with activity. Reports will be furnished to demonstrate achievements and if necessary, an inspection tour to a carefully selected site will be arranged. As soon as the inspection team leaves, these agencies revert to what they really are: freshly painted black and white signs. Such subterfuge is common at all levels of government. Wu Yi quotes the head of a township family planning office ${ }^{18}$ :

All higher-level inspections of family planning work are random; you don't know which village or which hamlet they'll visit, so there's a degree of surprise. But within the space of four to five days, we're able to coach every target household in every hamlet at least once, letting them know the contents and tricks of the inspection, so really there's no surprise.

He estimates that villages experience at least six family planning inspections annually (two from each of the prefecture, county and township), in addition to continuous surveillance by village cadres and the designated "family planning worker" in each hamlet. ${ }^{19}$ Thus, all target households are versed in coping with inspections.

Constant inspections were also a drain on township finances. In Benghai county, "entertainment expenses" ranked as the largest item of township government expenditure after salaries. Some townships have been more successful than others in reducing the burden of such expenses. One township close to the county seat had accumulated a debt of seven million yuan, and all interviewees cited "hosting guests" (jiedai 接待) as the main contributing factor. A large amount spent on entertainment, however, does not in itself indicate profligacy on the part of township leaders. As one county official explained, "it just means that the higher-ups like to dine there” (shangmian ai chi 上面爱吃). Wealthier townships see more inspection teams and thus run up larger debts. As a township leader explained to Zhao Shukai, remote townships "are rarely inspected by various higher-level departments and so have less to spend on entertainment." ${ }^{20} \mathrm{He}$ found that township leaders spent an average of 100 to 150 days per year on reception activities (one spent 300 days), and the expenses incurred from

footnote continued

perspective," The China Quarterly, No. 173 (2003), pp. 35-52; Zhao Shukai, "Rural governance," pp. 64-73; and Graeme Smith, "Political machinations in a rural county" The China Journal, No. 62 (2009), pp. 50-53.

$18 \mathrm{Wu} \mathrm{Yi,} \mathrm{Uproar} \mathrm{in} \mathrm{a} \mathrm{Small} \mathrm{Town,} \mathrm{p.} 585$.

19 Ibid. p. 590. See also Zhao Shukai, "Rural governance," pp. 23-25.

20 Zhao Shukai, "Rural governance," p. 39. 
"karaoke singing, sauna sessions and mahjong" accounted for between 5 and 10 per cent of fiscal income. ${ }^{21}$

Many township staff expressed the view that the main problem faced by township governments wasn't that they were overstaffed, but rather the capricious behaviour of leading cadres and the institutional dynamics of township government. ${ }^{22}$ In particular, they were exasperated that political machinations continued to trump government functions. As one noted: "We need to come out of this miasma of complex documents and targets set by higher levels, give up playing games on paper (wenzi youxi 文字游戏), and actually start providing services for ordinary people." A proliferation of documents meant that the township leaders were often bemused over how to govern. If an issue was receiving national attention, different higher-level bureaus would issue different documents, leading to “document wars" (wenzhang douzheng 文章斗争). The bureaus of forestry, agriculture and environmental protection were constantly at odds. In large part, the work of deputy township leaders was travelling to the county seat to settle these conflicts.

Township staff were quizzed as to whether they had any confidence in the direction township reform was taking, and what sort of reform of township government they felt was the best course. The results shown in Table 2 indicate a low level (18 per cent) of confidence in the current reform process.

The most widely accepted strategy for reform was to make the township an agency of the county government. In the view of many respondents, this reflected the existing balance of power between the townships and the county, ${ }^{23}$ and was the most effective way to cut out the middlemen - township Party leaders. As one noted: "Most professional work carried out by township agencies is directed by county departments. If the township government itself simply becomes a county agency, everyone can go about their work more effectively, and unnecessary friction between the township and county will be alleviated." Another argued: "With improvements in transportation and communications, this [model] suits current economic conditions, and reduces the capacity of township leaders to abuse their power and connive for personal gain." Zhao Shukai found that although this would amount to removal of their own authority, this was the opinion of half of the 20 township Party secretaries he interviewed. One Party secretary from Hunan explained: "The township governments just cannot cope with all the inspections from above. [They] are like firefighters with no definite duties ... all cadres are required to work together on all matters. Dismantling township governments will have no great effect on ordinary people. The biggest problem is where to put the township cadres." 24

21 Ibid. pp. 21-25.

22 This echoes Linda Chelan $\mathrm{Li}$, "Embedded institutionalization: sustaining rural tax reform in China," The Pacific Review, Vol. 19, No. 1 (2006), pp. 63-84. Li's arguments on the primary need for behavioural change among officials hold true for township governments in Benghai. At the county level, however, overstaffing is rampant, and is a major reason for cadre non-performance.

23 Kennedy, "From the tax-for-fee reform to the abolition of agricultural taxes," p. 45.

24 Zhao Shukai, "Rural governance," pp. 31-32. 


\section{Table 2: Attitudes towards Township Government Structural Reform (\%)}

\section{Level of confidence in current reforms}

Confident

Unsure

No confidence

Best course for reform

No need for change

County-level agency

Abolish township government

Take away some functions from the township

Other

Source:

Author's survey, 2006. $\mathrm{N}=95$.

\section{Soft centralization: differentiated experiences within township governments}

Andrew Mertha described the shifting of township or county agencies to provincial control as "soft centralization." A parallel trend has seen agencies previously controlled by township governments placed under the control of the county. The crucial distinction is whether the corresponding bureau at the county level has "leadership relations" (lingdao guanxi 领导关系) with the township bureau, or whether it only has "professional relations" (yewu guanxi 业务关系). Those which are under leadership relations and are thus controlled by their line bureau at the county level or above are referred to as "vertical agencies" (chuizhi danwei 垂直单位). Those with only professional relations to their line bureau are effectively controlled by township leaders, and are called “devolved work units" (xiafang danwei 下放单位).

Mertha observed that the first bureaus to undergo "soft centralization" to the provincial level were those associated with "administrative regulation, financial regulation and commodities management ... because of their vital role in China's economic development." 25 From the perspective of township leaders, the equation is simpler. Bureaus with "money and power" (you qian you quan 有钱有权) are claimed by higher levels of government, while those with neither money nor power, derogatively known as "clear water agencies" (qing shui yamen 清水衙门), are left under the control of township leaders.

To see whether the management status of an agency influenced its rank in the eyes of ordinary township government staff, respondents were presented with an open-response question (each township has different agencies, so a list would have been incomplete) as to which six township agencies enjoyed the best working conditions and salaries (daiyu zui hao 待遇最好). Table 3 shows the top ten township agencies in Benghai county, where only the lowest-ranked agency, the agricultural extension station, is under full township government control. 
Apart from vertical control, the most consistent thread between township agencies with superior working conditions is the ability to levy and - to differing extents - retain fees and fines to cover salaries, general office expenses and "entertainment." While vertical agencies are physically located in a township, the township Party and government organs in theory have no formal authority to control the leaders or even the staff of these agencies.

However, the independence of vertical agencies is not absolute. Their staff live and work in the township, and are subject to informal pressures. As an example, the rural credit co-operatives answer to the province, but township leaders, particularly the township Party secretary, exercise discretion over who can receive substantial loans. Similarly, if the township government opts to divert funds earmarked for flood relief, the finance and civil affairs agencies can be pressed to comply with little danger. The head of a township land management agency, which on paper answers to the county, explained the pressure to ignore the malfeasance of township leaders: "I have two wives. I should obey my first wife, but relatively speaking she's far away. My second wife is right here and nags me endlessly, so she usually gets what she wants." The heads of compliant agencies benefit financially, and the working conditions of these agencies will improve. The lack of funding for township governments has meant that embezzling earmarked project funds has gained acceptance among township government leaders and staff as a morally legitimate way to maintain working conditions. ${ }^{26}$ The practice is known as "knocking down the east wall to prop up the west wall" (chai dong qiang bu xi qiang 拆东墙补西墙).

While wealthy vertical agencies often attempted to separate themselves physically from the township government, creating "separatist regimes," 27 devolved agencies were unable to resist the opposite pressure from township leaders. The lack of physical boundaries between devolved agencies in many townships was striking. In one township, five different agencies shared one small room with only three desks: the agricultural extension station, the agricultural economic management station, the social insurance organization, the poverty alleviation office, and the broadcasting and culture station. Such an arrangement encouraged a collective approach to township government work. Whether collecting tax arrears, preparing for a family planning inspection or promoting the "new socialist countryside," township leaders preferred "all hands on deck." In the devolved agencies, professional boundaries were rarely respected.

Some staff in devolved agencies felt that the township leaders themselves were in an untenable position, that the proliferation of documents, meetings, inspections and other tasks received from higher levels made it difficult for the township

26 See Gu Wenfeng, Extraordinary Accounts, pp. 151-53; and Ray Yep, "Can 'tax-for-fee' reform reduce rural tension in China? The process, progress and limitations," The China Quarterly, No. 177 (2004), pp. $44-45$.

27 See Mertha, “China's 'soft' centralization,” pp. 804-05. 


\section{Table 3: Township Agencies with the Best Working Conditions}

\begin{tabular}{llcl}
\hline Agencies & & Mentioned by (\%) & Management \\
Finance & caizheng suo 财政所 & 100 & County \\
Party and government & dangzheng ban 党政办 & 71 & N/A \\
Family planning & jisheng ban 计生办 & 65 & County/township \\
Local tax & dishui ban 地税办 & 29 & Province \\
Police & paichu suo 派出所 & 26 & County \\
Land & tuguan suo 土管所 & 26 & County \\
Industry and commerce & gongshang ju工商局 & 23 & Province \\
Education & jiayu ban 教育办 & 21 & County/township \\
Civil affairs & minzheng ban 民政办 & 16 & County/township \\
Agricultural extension & nongji zhan 农技站 & 11 & Township
\end{tabular}

Source:

Author's survey, 2006, N=95; author's Interviews, 2004-08.

government to provide meaningful services to farmers. As one agricultural extension station head explained:

The township government is overrun with countless difficult issues (qian tou wan $x u$ 千头万绪), simply far too many to complete, so the township leaders usually have no time for agricultural extension work. That's not to say that they never will. Take last year as an example. The county pressured them to promote tea and bamboo processing, and suddenly I had their attention. But if there is the slightest let up in pressure from above, the township leaders disappear. It becomes a choice: they can pay it attention, or not. For the moment, the county is attentive, asking "How many demonstrations have you carried out? How much mountainous land has been reclaimed? What acreage of new tea plantations has been established?" County officials come to inspect, make reports, issue documents. ${ }^{28}$ So the township leaders pay attention. But otherwise nothing will happen, and there's no way they'd ever think about looking for new responsibilities. Without extreme pressure from above, they're numb and indifferent (wu qi wu li 无气无力).

This picture of township government officials bewildered by the number of higher level inspections and assessments matches that outlined by a State Council research team. ${ }^{29}$

Many interviewees felt that they had effectively become an extension of the township Party branch, responding to the priorities of township Party leaders, which tended to change according to the political wind of the day. Interviewees explained that the effect of this chaotic work schedule was "numbness" (mamu 麻木). Unable to work according to Weberian "calculable rules and "without regard for persons," "30 many township staff in devolved agencies, while nominally under the full control of the township leaders, paradoxically become harder to mobilize than staff in vertical agencies. With little prospect of promotion or recognition, and limited agency over their daily work, they shirk their duties. ${ }^{31}$

28 Several sources in the county government estimated that the average township would receive at least 1,000 documents per year from higher levels.

29 Duan Yingbi and Hongyuan Song (eds.), Zhongguo nongcun gaige zhongda zhengce wenti yanjiu baogao (A Research Report on the Major Policy Problems of Reform in Rural China) (Beijing: Zhongguo caizheng jingji chubanshe, 2004), p. 57.

30 Max Weber, Economy and Society, 2 vols. (Berkeley: University of California Press, 1978), p. 975.

31 Zhao Shukai, "Rural governance," pp. 70-73. 
Not all personnel within devolved agencies were keen to return to higher-level control, however, as past experience had taught them that weak county-level agencies were unable to provide financial security. ${ }^{32}$ The township agricultural economy station is rumoured to be returning to line management later in 2009, and many staff were uneasy about this development. As one explained:

We don't want to return to being a vertical agency (gui tiao 归条), because we don't want to be run by the county agricultural committee. Our wages and subsidies [for meals and transport] are guaranteed by the finance bureau, but if we go back to line management, there's no way the higher-ups will pay for our subsidies. Nor will the township government pay, because you're no longer managed by them.

While township staff tended to refer to "township leaders" as a whole, this group was sharply divided in terms of which interests it served. Township Party secretaries and township heads, selected by the county standing committee, were as a rule chosen as "a pair" and would generally work together to further their political interests. Rather than residing in their township, as was the norm during the 1980s and 1990s, township Party secretaries usually live in the county seat and commute to the township when required. However, older deputy township leaders who saw little prospect of promotion to the county level owe less fealty to the county leadership, and often lobbied against projects initiated at the county level or above, or acted to protect their own network of local business interests.

With township leaders frustrated, focused on their future careers, and spending large amounts of the year outside the township attending meetings or entertaining potential investors, a power vacuum has emerged in many townships. The office managers (bangongshi zhuren 办公室主任) who head the township administrative offices control access to the Party secretary, and thus wield disproportionate influence. They co-ordinate township government staff during the long periods when township leaders are away. While most township government agencies (apart from family planning, finance and the police) are usually deserted, one office manager has eight staff working under him, including a driver. Like their counterparts at the county level, their authority derives from the ill-defined limits of their powers. Many new township Party secretaries appoint their own office manager, usually a trusted personal friend whom they previously relied upon while working in the county government.

Faced with resistance from staff in vertical agencies which no longer answer to them, frustrated by unmotivated staff in devolved agencies, and pressured from above by county leaders and an endless stream of inspections, township leaders also often felt they weren't able to do real work. "Soft centralization" may have succeeded in shifting the locus of power upwards to the county and provincial levels, but the goal of building a more modern and compliant bureaucracy at the township level seems elusive. While the abolition of agricultural taxes in 2006 
means that the township government has lost much of its traditional extractive function, centralization has weakened the cohesiveness of the township bureaucracy.

\section{Hollowed from Below: Sent-Down Cadres and Family Planning}

\section{Sent-down cadres}

In addition to a core staff of three to five native village cadres (Party secretary/ village head, deputy Party secretary/village head, village clerk, women's cadre), villages usually contain several cadres from the county and township governments. Allocating staff to villages is usually the first item of business for a new township government, and lobbying of township leaders by staff to be sent to a "good" village is intense. This practice of cadres from higher levels being responsible for a given village was a crucial aspect of the county government's efforts to control and monitor village governments, ${ }^{33}$ and had the effect of drawing a large number of staff out of the township government. For younger township cadres, working as a sent-down cadre enhances their prospects of promotion. However, being assigned to a village with many "problem households" (dingzi hu 钉子户) can severely harm their political prospects, as they face a system of financial and political punishment for any disturbances in their allocated village. This has led to infighting among township cadres during the period leading up to a change in township leaders.

One administrative village that I visited had six sent-down cadres (one from the county industrial and commercial bureau, five from the township), outnumbering the five regular village cadres, and most villages have at least three township cadres. Commonly, managing a village is either accepted as a "task" (renwu 任 务) or resented as a waste of both the villagers' time and their own. As one former township cadre explained:

Back in 2005, I was about to be sent down to a village, but I got out just in time [to a post in the county government]. I'd worked in the township government for more than ten years, so there was no way I wanted to be sent down, I'd still be stuck working there now. It would have been almost impossible to escape at my age. They call it "training" (duanlian 锻炼), but township government work is in the villages, dealing with the peasants. After such a long time, you know the villages inside out, there are no mysteries. What training? It's meaningless.

Many county government officials admitted that the practice was not just an effort to reassert control over village governments, but also a direct result of pressure to streamline township governments.

33 Another development with a similar impact was the combining of the posts of village Party secretary and (formerly elected) village head, referred to as "taking the load on one shoulder" (yi jian tiao). This had been implemented in $60 \%$ of Benghai's administrative villages, meaning that nearly two-thirds of village leaders were effectively appointed by township governments. This is in keeping with developments elsewhere in China, and has had the unintended consequence of increasing intra-village tensions between clans. See Gu Wenfeng, Extraordinary Accounts, pp. 176-78. 
There are regional variations. One village head from Liaoning province told me that in his area they would not tolerate sent-down cadres because villagers saw them as an infringement of the village's sphere of self-governance. ${ }^{34}$ At the other end of the spectrum, another researcher in northern Anhui found that practically all township cadres, with the exception of the township Party secretary and the township head, were working as sent-down cadres. ${ }^{35}$ Provincial sources suggest that from 2000, as streamlining reforms were undertaken in earnest, the number of sent-down cadres increased. ${ }^{36}$ The county government had also amassed cadres from the central, provincial and prefectural governments. ${ }^{37}$

Zhao Shukai suggests that sent-down cadres are required in two types of villages: those that have been selected as showcase model villages for inspections by higher levels of government (the "new socialist countryside" programme has proved a boon to these already privileged villages), and those where there have been disturbances or signs of an emerging crisis. ${ }^{38}$ However, in Benghai the practice is routine for all administrative villages, and the number of sent-down cadres in a village increases with proximity to the county seat. Asked whether there were many meetings attended by village leaders in the township, one cadre declared: "There's no need. Every village has several township cadres staying in it. If the upper levels have any fresh instructions, we just inform those cadres." The number of cadres sent down from the townships was so numerous that they were divided into three different categories, according to rank: senior cadres, ordinary cadres and family planning liaison personnel.

In addition to sending out a substantial proportion of their staff, township leaders routinely interfere in village elections, often playing "moral politics." 39 Few village cadres were sacked without a well-publicized reason. One village Party secretary was axed for his perceived corruption in managing a village-run coalbrick factory during the 1990s, while a village head was removed after being involved in protracted divorce proceedings. Villagers concurred that if he could not run his own family, he was unfit to manage the village. Replacements for "failed" village leaders invariably had a strong backer in the township government, usually a well-placed relative.

The salaries of village cadres in Benghai are now paid entirely from the township government budget, rather than drawing income from village enterprises or from a percentage of collected taxes. In Benghai county, village governments are now effectively outposts of township governments, and largely respond to the

34 Author's interview, Beijing, April 2006.

35 See Man, Sent-Down Cadres and Village Self Governance.

36 Author's interviews, Anhui Academy of Social Sciences, November 2008.

37 Smith, "Political machinations," pp. 35-38.

38 Zhao Shukai, "Xiang cun guanxi: zai kongzhi zhong tuojie" ("Township-village relations: dislocated control"), Huazhong shifan daxue xuebao (Journal of Huazhong University), Vol. 44, No. 5 (2005), p. 4.

39 Hok Bun Ku, Moral Politics in a South China Village: Responsibility, Reciprocity, and Resistance (Lanham: Rowman \& Littlefield, 2003). 
priorities of their superiors in the township. ${ }^{40} \mathrm{He}$ who pays the piper calls the tune, and in Benghai county the tune in the villages is family planning.

\section{Family planning}

As well as the amount of tax collected (which ceased to be an important criterion in 2006), one aspect of government work has remained paramount for assessing the performance of townships since the 1980s: family planning. Indicators for success in implementing family planning policies have grown more complex over time, which partly explains why this now occupies township and village governments' time and resources. A county notice states how many points each task will be worth in the sent-down cadres' annual assessments (Table 4).

The "one-strike rejection policy" is attached to family planning targets in the township government's annual assessment and in the individual assessments of sent-down cadres, and reinforced by regular inspections by higher levels of government. One direct consequence is that township agencies are hollowed out from within by pressure to divert resources to family planning. To illustrate this, I provide information on the staffing situation within the agricultural extension stations of Benghai's 16 townships. These surveys revealed that a majority of township agricultural extension agents spent most of their time on tasks unrelated to extension work. Indeed, many went through 2005 without doing a single day of extension work. The main agency they worked for was the family planning office. The breakdown of Benghai's township extension agents in terms of their actual workplaces is shown in Table 5 .

Table 5 indicates that in 2005 only 26 per cent of Benghai's agricultural extension workers actually worked as extension agents, with an equal number working for the family planning office. Given that sent-down village cadres have been shown to spend most of their time on family planning work, at least 37 per cent of extension agents were devoting all or most of their time to implementing family planning policy. An equal number had been transferred to the townships' family planning agencies, with the remainder working in the villages or in other township agencies which were deemed to be current priorities. This phenomenon of "not doing one's real job" (wu bu zheng ye 务不正业) was common to all township government agencies.

The figure of 26 per cent working as extension agents is almost certainly an overestimate. Many held "concurrent posts" (jianzhi 兼职) making it difficult to determine whether their main work was agricultural extension or the duties associated with their "concurrent post." Where possible, these extension agents were asked what the bulk of their work entailed, but where it was not possible

40 There are caveats to this. If a village is home to an influential cadre from a higher level of government, the township can, to an extent, be bypassed by the village government, particularly in attracting investment. 


\section{Table 4: Assessment Criteria for Sent-down Village Cadres}

\begin{tabular}{lr}
\hline Assessment criteria & Points \\
Family planning & 30 \\
Ecological support (agriculture, forestry, irrigation, technical training, establishing & 15 \\
$\quad$ agribusinesses) & 10 \\
Public stability (law and order, petitions, safe work practices) & 5 \\
Establishing grassroots organizations & 5 \\
Establishing basic infrastructure & 5 \\
Finance and agricultural economic work & 4 \\
Creating civilization (propaganda work, public health, markets) & 4 \\
Cadre work style & 4 \\
Developing the collective and private economy & 4
\end{tabular}

Notes:

Notice on the methods for implementing point-scoring assessments of sent down village cadres, Town Y, 2006.

Items scoring three points or less: transitional work, militia training, attracting investment, land management, civil administration, education, record keeping and social security.

to interview them it was assumed that their main task was agricultural extension. Even staff who were officially "full-time" (zhuanzhi 专职) extension agents often admitted that they did little or no extension work. The head of one extension station, who was annually awarded the title of “excellent" (youxiu 优秀) by the county agricultural committee, admitted that since 2001 (when township extension stations were devolved) he was lucky to spend more than 30 days each year doing his job.

Village cadres made little pretence that their work involved much beyond family planning. Male cadres often joked that the women's cadre (in charge of

\section{Table 5: Actual Work Units of Township Agricultural Workers}

\section{Agency/station}

Agricultural extension

Family planning

Sent-down village cadres

Social insurance

Township government office

Party and government

Agricultural supply business

Industrial estate management committee

Industry and commerce

Urban planning

Urbanization and civilization

Residential area

Projects and investment

Ecology nongji zhan 农技站 26

jisheng ban 计生办 26

xiapai cunji ganbu 下派干部 11

shehui baoxian $z u$ 社会保险组 9

xiangzhen zhengfu bangongshi 乡镇政府办公室 7

dang zheng ban 党政办 3

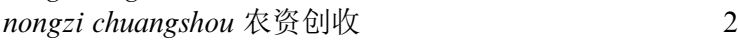

gongyuan qu guanli weiyuanhui 公园区管理委员会 2

gongmao ban 工贸办

chengzhen guihua ban 城镇规划办

chengjian wenming ban 城建文明办 1

shequ 社区 1

zhaoshang ban 招商办 1

shengtai ban 生态办 1 
family planning) was the only one with a real job, and that the other village cadres were just her assistants. In one internal note listing the allocation of tasks among the newly elected cadres of a relatively wealthy village, family planning was mentioned eight times, far more frequently than other priorities, such as "compiling personnel files" (twice), "public stability" (once) and "creating spiritual civilization" (once). The emphasis on family planning was confirmed in this village's budget. The main listed expenditure items for 2005 were two trips to track down pregnant women who had fled the county. The only listed item of income was 25,000 yuan from the township government, ${ }^{41}$ but the real figures for entertainment expenses are never listed, nor are salaries. By 2008, like many villages in Benghai, the village had been forced to hire an additional staff member to work on family planning.

\section{Conclusions}

What does the view from the inside tell us about the nature of the local state in rural townships? Most of the actors are making the best of what is often quite a poor hand. Township Party secretaries and younger sent-down village Party secretaries from the county are typically hard-working, doing their best to extract visible results that will impress their superiors in the county government, which they hope will lead to promotion to a better remunerated and less taxing post. As leading cadres see their future in the county, the county government enjoys considerable control over the priorities of township governments.

With higher levels of government placing pressure on them to cut costs and streamline staff, and an increasing number of bureaus placed outside their formal control as vertical agencies, township Party leaders have responded by tightening their control over devolved agencies and villages, sending out their surplus cadres to ensure that village cadres enforce the key tasks of family planning and social stability, and ensuring that "their" candidates control the activities of village governments. Concurrently, the most able township cadres are leaving their posts to spend ever-increasing amounts of time outside the province in the hope of securing industrial investment, satisfying both the political imperatives of the annual assessments system, and the revenue imperatives of county and township governments. While during the 1980s and 1990s the township Party secretary could readily be found in the township government compound, the day-to-day running of hollowed-out township governments is now left to office managers and the least-talented staff.

41 There are still many ways by which village cadres can squeeze extra revenue from their constituents to cover their entertainment expenses. With the increased social security coverage, village cadres can use their discretionary control to extract revenue from the poorest rural residents. If villagers refuse to "give back" a percentage of the minimum living allowance (set at 860 yuan per year in 2008), cadres will direct the funds elsewhere. 
618 The China Quarterly, 203, September 2010, pp. 601-618

Such hollowed-out organizations are unable to play an active role in rural communities, and there are ingredients in the current structure of rural governance that are anathema to service provision, and will undermine attempts to transform township governments into "service-oriented" agencies. Without a move away from the practice of administrative coercion, and the "one-strike rejection" that gives rise to it, the local state will continue to view farmers as problems, rather than as clients or citizens. 